\title{
Ciri Khas Gaya Pembelajaran Elemen Persekitaran dan Elemen Fisiologi Murid Lemah untuk Belajar dan Memproses Maklumat Baru
}

\author{
Nurulhuda Md Hassan', Mohd Razimi Husin', Hishamuddin Ahmad ${ }^{1}$, Faridah Hanim \\ Yahya $^{1}$ \\ ${ }^{1}$ Department of Educational Studies, Faculty of Human Development. Universiti \\ Pendidikan Sultan Idris. Tanjong Malim, Malaysia.
}

Article History
Received:
14.10 .2021
Revised:
23.11 .2021
Accepted:
14.12.2021
*Corresponding Author:
Nurulhuda Md Hassan
Email:
nurulhuda.mh@fpm.upsi.
edu.my

This is an open access article, licensed under: $\mathrm{CC}-\mathrm{BY}-\mathrm{SA}$
Abstrak: Kajian ini bertujuan untuk mendedahkan tentang penerimaan murid dalam kemahiran dan maklumat pembelajaran yang dilakukan di sekolah rendah. Kajian ini juga bertujuan untuk memahami ciri khas gaya pembelajaran elemen persekitaran dan elemen fisiologi murid yang lemah berdasarkan kecenderungan mereka untuk belajar dan kemampuan memproses maklumat baru. Kajian ini adalah kajian kes yang menggunakan data kualitatif untuk menjawab persoalan yang dinyatakan. Penyelidik menggunakan Model Dunn \& Dunn sebagai panduan dalam menganalisis data pemerhatian dalam gaya pembelajaran yang disokong oleh wawancara dan analisis hasil kerja murid. 16 peserta dipilih dengan sengaja untuk kajian ini. Dapatan menunjukkan bahawa rangsangan gaya pembelajaran elemen persekitaran dan elemen fisiologi mendorong atau merangsang pembelajaran murid yang lemah. Kesimpulannya, di samping strategi yang baik, gaya pembelajaran sebagai petunjuk pembelajaran dan pencapaian yang meningkatkan kualiti penerimaan maklumat murid. Oleh itu, penemuan ini merungkai hubungan antara gaya pembelajaran dan kesan pembelajaran murid yang perlu diberi perhatian oleh pendidik untuk memenuhi pengajaran dan cara pembelajaran murid.

Kata Kunci: Elemen Fisiologi, Elemen Persekitaran, Gaya Pembelajaran.

Special Characteristics of Learning Styles Environmental Elements and Physiological Elements of Weak Students to Learn and Process New Information

Abstract: This study aims to reveal about the acceptance of students in the skills and information of learning done in primary schools. This study also aims to understand the special characteristics of learning styles of environmental elements and physiological elements of weak students based on their propensity to learn and ability to process new information. This study is a case study that uses qualitative data to answer the stated questions. Researchers used the Dunn and Dunn Model as a guide in analyzing observational data in a learning style supported by interviews and analysis of student work outcomes. 16 participants were deliberately selected for this study. Findings indicate that learning style stimuli of environmental elements and physiological elements induce or stimulate poor student learning. In conclusion, in addition to good strategies, learning style as an indicator of learning and achievement that improves the quality of student information reception. Therefore, these findings unravel the relationship between learning styles and student learning effects that need to be given attention by educators to meet the teaching and learning methods of students.

Keywords: Environmental Elements, Learning Styles, Physiological Elements. 


\section{Pendahuluan}

Pelbagai usaha telah dilaksanakan bagi meningkatkan mutu pendidikan negara dalam semua mata pelajaran dan salah satu usaha untuk meningkatkan mutu pendidikan adalah melalui peningkatan mutu pembelajaran murid-murid. Peningkatan mutu pembelajaran murid-murid tersebut hendaklah mengambil kira pengalaman, pandangan dan tanggapan murid itu sendiri terhadap muridnya. Selain itu, penguasaan isi kandungan mata murid dan kemudahan guru dalam bidang pengkhususan akan merancakkan lagi proses pembelajaran murid berkualiti mengambil kira faktor guru kerana guru mampu membaiki pencapaian murid melalui pengajaran berkualiti [1].

Kajian tentang gaya pembelajaran banyak dilakukan [2] [3] [4] [5] [6] [7] [8] [9] [10] [11] [12] [13] [14] [15] [16] [17] [18] [19] [20] [21]. Namun, kebanyakan kajian tersebut tidak memberi fokus utama kepada gaya pembelajaran sebagaimana yang dilaksanakan oleh Pyle [22] yang memberi fokus kepada kerja rutin. Kajian Fine [23] mendapati, pembelajaran yang mengambil kira gaya pembelajaran murid akan memberi kesan yang besar kepada peningkatan pencapaian, sikap dan tingkah laku. Fine yang melihat secara statistik menjelaskan bahawa murid memperoleh pencapaian yang lebih tinggi dan sikap yang menyenangkan melalui pengajaran berasaskan gaya pembelajaran.

Kajian lain menunjukkan bahawa murid-murid yang belajar dengan gaya pembelajaran, mempunyai prestasi yang lebih baik daripada mereka yang belajar tanpa mengambil kira gaya pembelajaran [24]. Oleh itu, kajian yang lebih khusus dan menyeluruh perlu dilaksanakan dengan memberi fokus kepada ciri-ciri gaya pembelajaran dalam bentuk kajian kualitatif hasil daripada data pemerhatian, temu bual dan analisis hasil kerja murid.

Persekitaran sekolah telah mempengaruhi pembelajaran murid. Persekitaran fizikal, persekitaran pembelajaran dan persekitaran sosial saling berkait antara satu sama lain dalam menentukan objektif pembelajaran murid. Jais et al. [25], telah mengkaji tentang kesan kepada pembelajaran murid apabila warga sekolah mempunyai sikap positif atau negatif terhadap mereka. Kesemua faktor persekitaran tersebut mungkin memberi kesan kepada pembentukan sikap murid. Menurut Gagne [26], pembentukan sikap akan mempengaruhi gaya pembelajaran murid. KPM [27] telah menyarankan agar kaedah yang digunakan dalam PdP memudahkan murid menerima dan memahami kandungan. Persekitaran pembelajaran yang sesuai adalah penting dalam pelaksanaan PdP [28] dan boleh mempengaruhi gaya pembelajaran [29].

\section{Metodologi}

Kajian ini menggunakan pendekatan kualitatif yang menggunakan jenis kajian kes. Kajian kes terhadap murid-murid akan menunjukkan keperluan sebenar mereka dan guru-guru boleh merancang untuk memenuhi keperluan tersebut [30]. Murid yang dipilih adalah murid yang boleh berinteraksi dengan dan mempunyai potensi untuk meningkatkan dan mengembangkan diri mereka.

Kajian ini menggunakan Model Gaya Pembelajaran Dunn dan Dunn sebagai panduan dan modelmodel lain sebagai sokongan untuk membentuk struktur pemerhatian kerana kajian terkini berasaskan model Dunn dan Dunn digunakan terhadap murid-murid masalah pembelajaran. Menurut Cassidy [31], skala soal selidik Dunn, Dunn dan Prices adalah untuk kegunaan sekolah rendah dan sekolah menengah. Dapatan daripadanya boleh digunakan untuk menentukan situasi pembelajaran, peralatan dan pendekatan pengajaran. Kajian ini menggunakan kaedah pemerhatian, temu bual dan dan analisis hasil kerja murid.

\section{Dapatan Kajian}

Ciri-ciri Gaya Pembelajaran elemen persekitaran murid lemah sekolah rendah.

\subsection{Gaya Pembelajaran Stimulus Persekitaran}

Stimulus Persekitaran berdasarkan Model Dunn dan Dunn adalah berasaskan unsur bunyi, cahaya, suhu dan pola [32]. Stimulus persekitaran dalam gaya pembelajaran sebagaimana yang ditunjukkan dalam Jadual 2 memperlihatkan bahawa sebahagian besar murid di S1 dan S2 mempunyai ciri-ciri gaya pembelajaran Model Dunn dan Dunn bagi menghasilkan PdP yang membolehkan mereka menerima maklumat dan kemahiran dengan berkesan. Walau bagaimanapun ciri-ciri khusus gaya pembelajaran murid dapat di lihat dalam kajian kes ini.

Berdasarkan Jadual 1, stimulus persekitaran yang dimiliki bersama-sama oleh murid-murid ini adalah bunyi. Stimulus persekitaran merupakan stimulus yang penting untuk murid menerima ilmu dan kemahiran kerana semua murid memerlukan kesemua unsur ini kecuali pada unsur bunyi yang mana mereka memerlukan keadaan yang senyap. Kesimpulan yang dapat dibuat daripada stimulus 
persekitaran ini ialah murid-murid menerima kemahiran atau maklumat dalam suasana yang selesa dan kondusif di sekolah dengan ciri-ciri persekitaran yang memudahkan dan sesuai untuk seseorang murid belajar.

Jadual 1. Stimulus Persekitaran MURID M1-M3 di S1 dan S2

\begin{tabular}{ccccc}
\hline \multirow{2}{*}{ GPMURID } & \multirow{2}{*}{ Sekolah } & \multicolumn{3}{c}{ MURID } \\
\cline { 2 - 5 } & & $\mathrm{M} 1$ & $\mathrm{M} 2$ & $\mathrm{X}$ \\
\hline \multirow{2}{*}{ Bunyi (Senyap) } & $\mathrm{S} 1$ & $\mathrm{X}$ & $\mathrm{X}$ & $\mathrm{X}$ \\
\cline { 2 - 5 } & $\mathrm{S} 2$ & $\mathrm{X}$ & $\mathrm{X}$ & $\mathrm{X}$ \\
\hline
\end{tabular}

Ciri-ciri yang diperlihatkan telah menunjukkan individu cenderung dan boleh menerima maklumat dan kemahiran yang disampaikan melalui pembelajaran di dalam bilik darjah yang senyap, keadaan cahaya yang terang, suhu bilik dan pola tempat duduk yang formal sebagaimana yang dijelaskan berikut ini.

Unsur bunyi dalam Stimulus persekitaran menyentuh kepada murid cenderung dan boleh menerima maklumat dan kemahiran yang disampaikan melalui pembelajaran di dalam bilik darjah dengan disertakan bunyi-bunyian tertentu sebagaimana yang dicadangkan oleh Dunn dan Dunn. Dapatan menunjukkan tiada bunyi yang membuktikan kecenderungan murid dalam menerima maklumat dan kemahiran yang disampaikan dengan baik atau mempunyai kualiti pembelajaran yang baik.

Data penyelidikan juga mendapati tiada proses PdP yang dilaksanakan guru bagi membolehkan penyelidik melihat kecenderungan mana-mana ciri unsur bunyi. Dapatan pemerhatian menunjukkan dapatan yang berbeza. Sebahagian murid dapat belajar walaupun terdapat bunyi bising (M1S1 \& M2S1 OS1:002). Farzana (M2S1) tidak menghiraukan bunyi mesin rumput di luar disebabkan kekhusyukan belajar. Begitu juga keadaan yang berlaku kepada Mahfuz (M3S1) yang mampu belajar dalam suasana bising kerana kekhusyukan belajar. Walau bagaimanapun, maklumat melalui temu bual murid, guru dan ibu bapa menunjukkan murid tidak boleh belajar dengan sempurna sekiranya terdapat bunyi-bunyian semasa belajar. Farzana (M2S1) menyatakan tidak suka belajar dalam keadaan ada bunyi atau lagu (TS1:009) dan begitu juga Hazim (M2S2). Selain bising kelas sebelah, bunyi-bunyi audio juga akan mengganggu tumpuan murid untuk belajar dengan sempurna sebagaimana dinyatakan Ustazah Nurul (G1S1 TS1:023). Ibu bapa juga bersetuju bahawa anak mereka tidak sesuai belajar di tempat yang terdapat bunyi-bunyian dan perkara yang mengganggu konsentrasi seperti belajar sambil menonton televisyen (IB M1S2 TIB:030).

Oleh itu, sebelum guru menentukan pendekatan dan kaedah yang sesuai digunakan dalam PdP murid, guru perlu memastikan murid berada di kelas yang jauh daripada kebisingan kerana sebahagian murid sensitif dengan bunyi bising yang menyebabkan mereka tidak dapat menumpukan perhatian sepenuhnya kepada mata pelajaran. Walaupun tidak semua murid sensitif dengan kebisingan namun semua MURID dapat belajar dengan lebih sempurna dalam keadaan yang jauh daripada kebisingan. Contoh lain, M3S1 dalam pemerhatian didapati tidak dapat menumpukan perhatian dengan kebisingan (M3S1 OS1:006).

Walaupun kadang-kadang didapati M3S1 kelihatan tidak terganggu dengan bising kelas sebelah, namun dia sensitif dengan bunyi bising mesin rumput dan pada masa yang lain terganggu dengan bising kelas sebelah. Bunyi-bunyi tersebut menyebabkan M3S1 tersentak dan hilang tumpuan belajar. Kesimpulannya, sama ada pemerhatian dan temu bual yang dijalankan kepada MURID, guru atau ibu bapa menunjukkan MURID tidak memerlukan bunyi-bunyian sama ada bunyi latar atau selainnya. Mereka dapat menumpukan kepada pembelajaran apabila suasana senyap dan tidak ada gangguan bunyi.

\subsection{Gaya Pembelajaran Stimulus Fisiologi}

Stimulus fisiologi mengandungi empat unsur iaitu persepsi, makan, masa dan pergerakan. Unsur persepsi melibatkan ciri individu yang suka belajar dengan benda atau pengalaman maujud atau sebaliknya dengan perkara abstrak. Unsur makan melibatkan ciri individu yang suka atau sebaliknya 
tidak suka makan dan minum semasa belajar. Unsur waktu melibatkan ciri individu yang suka belajar pada waktu yang sesuai atau sebaliknya pada bila-bila masa sahaja. Unsur gerakan melibatkan ciri individu yang suka atau sebaliknya tidak suka bergerak semasa belajar.

Sebahagian besar jawapan terhadap persoalan ini datang daripada pemerhatian dan temu bual MURID sendiri. Persoalan gaya pembelajaran MURID dalam pengajaran dan pembelajaran (PdP) sebagaimana yang ditunjukkan dalam Jadual 2 memperlihatkan bahawa sebahagian besar MURID di S1 dan S2 adalah memiliki gaya pembelajaran stimulus fisiologi yang terdapat dalam Model Dunn dan Dunn.

Jadual 2. Stimulus Fisiologi Pendidikan Islam MURID M1-M3 di S1 dan S2

\begin{tabular}{cccccccc}
\hline $\begin{array}{c}\text { Gaya Pembelajaran } \\
\text { MURID }\end{array}$ & Unsur: & M1S1 & M2S1 & M3S1 & M1S2 & M2S2 & M3S2 \\
\hline Persepsi & & $\mathrm{X}$ & $\mathrm{X}$ & $\mathrm{X}$ & $\mathrm{X}$ & $\mathrm{X}$ & $\mathrm{X}$ \\
\hline
\end{tabular}

Tidak semua unsur pada stimulus fisiologi dimiliki oleh peserta kajian. Namun, mereka memiliki unsur persepsi, masa, pergerakan dan stimulus-stimulus yang dikategorikan sama dalam stimulus fisiologi. Semua ciri-ciri yang wujud akan dibincangkan satu persatu berikut ini.

Stimulus Fisiologi berunsur persepsi melibatkan pembelajaran dengan benda atau pengalaman maujud. Data yang diperoleh menunjukkan MURID suka belajar melalui visual, audio dan pengalaman yang akan dirasai sendiri. Pembelajaran melalui visual adalah melalui penggunaan nota atau alat di papan putih dan skrin komputer riba. Hal ini dapat diperoleh melalui temu bual terhadap Azam (M1S2) yang memberi tumpuan semasa guru mengajar menggunakan alat bantu pada papan putih apabila ditanya perkara yang disukai (M1S2 TS2:029).

Guru MURID menyatakan, kad yang ditampal pada papan putih adalah lebih baik jika dibandingkan bahan fotostat (G2S2 TS2:026). Manakala rakaman video terhadap Farzana (M2S1) yang memberi tumpuan semasa guru mengajar menggunakan bantuan nota pada papan putih (M2S1 RVS1:004). Tambahan lagi Farzana (M2S1), seronok apabila guru menggunakan papan putih semasa mengajar Iqra' walaupun gurunya tidak selalu menggunakan papan putih kerana lebih banyak menggunakan buku Iqra'. Ini dapat didengar melalui penjelasan Farzana apabila ditanya tentang pembelajaran menggunakan bantuan papan putih (M2S1 TS1:009). Begitu juga dengan Hazim (M2S2) yang suka dan selalu belajar berbantukan nota pada papan putih (M2S2 TS2:012).

Melalui unsur persepsi juga, selain ciri alat bantu yang digunakan bersama-sama dengan papan putih, didapati juga ciri skrin yang ditunjukkan oleh MURID dalam pembelajaran melalui visual. Guru menggunakan kaedah yang menggunakan bahan bantu mengajar seperti penerangan yang berbantukan skrin komputer yang boleh menarik minat murid. Antara kandungan mata pelajaran melalui aktiviti visual skrin adalah kisah-kisah nabi, al-Quran dan Jawi.

Ibu Hazim memberitahu, anaknya Hazim memang suka menonton televisyen dan melayan permaianan pada komputer riba dirumah (IB M2S2 TIB: 030). Pengaruh tersebut dibawa dalam pembelajaran. Begitu juga apabila ditanya dalam temu bual, Farzana (M2S1 TS1:009) menyatakan bahawa dia suka belajar yang melibatkan pandangan pada skrin komputer. Kesukaan ini turut dikongsi bersama-sama dengan Azam (M1S2) yang menyatakan dia suka kepada kedua-dua teknik yang digunakan sama ada belajar berbantukan papan putih atau skrin komputer (M1S2 RS2:010). Bukan sekadar suka sahaja, malah MURID akan mengikut bacaan yang ditayangkan pada skrin (M2S2 RVS2:050). Ustazah Lina akan menarik semangat muridnya dengan membuat janji (M2S2 OS2:050).

Nampaknya, pembelajaran dengan alat di papan putih dan skrin komputer merupakan gaya pembelajaran MURID pada unsur persepsi ciri visual. Oleh itu guru perlu kepada pendekatan dan kaedah yang menggunakan bahan bantu mengajar yang sesuai seperti penerangan di papan putih berbantukan alat yang sesuai dan menggunakan layar skrin yang boleh menarik minat murid.

Selain ciri visual, didapati juga ciri audio yang ditunjukkan oleh MURID dalam pembelajaran. Ciri audio yang dimaksudkan bukanlah melibatkan aktiviti penerangan semata-mata, malah melibatkan aktiviti penyampaian guru melalui kaedah bercerita. Kaedah bercerita didapati mampu menarik minat 
murid untuk belajar (M2S2 RVS2:003). MURID juga suka kepada audio yang melibatkan lagu. Mereka memberi tumpuan apabila guru mengajar dengan memperdengarkan lagu (M1S1 TS1:011). Begitu juga dengan Hazim (M2S2) yang suka dan rasa seronok, mudah ingat dan faham apabila belajar melalui audio lagu (M2S2 TS2:012).

Nampaknya MURID di kedua-dua sekolah cenderung belajar menggunakan deria pendengaran yang melibatkan cerita atau lagu. Perkara yang paling menarik adalah apabila lagu yang diminati adalah kategori nasyid. Nasyid merupakan lagu yang sinonim dengan Pendidikan Islam. Penyelidik menjadikan nasyid satu stimulus yang khusus kerana amat bersesuaian dengan mata pelajaran Pendidikan Islam yang menggunakan stimulus lagu. Stimulus lagu nasyid ini menjadi kegemaran Hazim (M2S2) yang menyatakan bahawa dia suka dan seronok tengok video nasyid yang selalu dijadikan bahan bantu mengajar oleh gurunya (TS2:027). Manakala Mahfuz pula akan menyanyi lagu Nama Nabi apabila ditanya tentang nasyid. Malahan, dia akan berusaha sendiri untuk mendengar lagu-lagu nasyid di luar sekolah (M3S1 TS1:017).

Selain daripada unsur yang telah dinyatakan, MURID juga cenderung belajar dengan melaksanakan dan merasai sendiri pengalaman pembelajaran. Antara pengalaman yang mempunyai kaitan dengan stimulus lagu adalah ciri pengalaman nyanyi iaitu belajar dengan aktiviti menyanyi. MURID akan mengingati seni kata lagu bagi tayangan yang berulang (M2S2 RVS2:052). Selain pengalaman menyanyi, aktiviti lain yang sesuai bagi mereka adalah mewarna, amali, amali saghir dan latihan bertulis. Semua MURID cenderung belajar dengan aktiviti mewarna. Sebagai contoh dalam pemerhatian kepada Hazim (M2S2 RV:003).

Aktiviti mewarna merupakan aktiviti menggunakan lembaran kerja yang diminati oleh murid berdasarkan laporan temu bual dengan guru dan juga perlakuan murid yang tekun melaksanakan aktiviti tersebut. Namun aktiviti ini tidak memberi kesan kepada pembelajaran murid sekiranya tiada interaksi dilakukan kepada gambar yang diwarnakan.

Aktiviti mewarna ini telah dibincangkan pada unsur sendirian yang menunjukkan MURID minat dengan aktiviti ini secara sendirian dan dilakukan dengan baik. Ini dapat diperhatikan melalui pemerhatian terhadap (M1S2 OS2: 032).

Dalam situasi yang sama Hazim (M2S2) dan Syafik (M3S2) membuat lembaran kerja mewarna dengan tekun (OS2:032). Kecenderungan seperti ini turut disokong sendiri oleh murid yang sama dalam temu bual (M1S2 TS2: 010). Mewarna gambar yang disediakan pada lembaran kerja bukan sahaja dapat meningkatkan kemahiran motor halus, malah membantu MURID mengingati kemahiran pada rukun fi'li solat selepas tindakan susulan daripada guru iaitu bertanyakan tentang gambar yang diwarnakan. Jawi merupakan bidang lain selain daripada solat yang menjadi kegemaran MURID untuk aktiviti mewarna (M2S2 TS2:027).

Ciri pengalaman yang lain ditunjukkan oleh MURID adalah melibatkan pengalaman melalui amali. Terdapat dua bahagian amali iaitu amali kabir dan amali saghir. Amali kabir disebut amali sahaja iaitu pengalaman melalui amali berlaku apabila MURID cenderung belajar dengan melaksanakan kemahiran sebenar atau melalui tunjuk cara. Manakala amali saghir adalah menunjukkan kemahiran di tempat duduk dan bukan pada situasi sebenar atau tunjuk cara (M1S2 OS2: 074). Tambah lagi, Azam (M1S2) mengakui sendiri dalam temu bual bahawa pembelajarannya lebih berkesan dengan amali tersebut berbanding melalui pembelajaran teori sahaja. Selain amali solat, Azam boleh belajar dengan lebih berkesan melalui aktiviti amali untuk tajuk wuduk (M1S2 TS2:004). Begitu juga Hakim (M1S1) suka menunjukkan cara melalui perbuatan (M1S1 RVS1:002). Amali wuduk dan solat yang dilakukan di surau amat berkesan kerana perbuatan tersebut bukan sahaja digemari murid dan tempatnya selesa, tetapi dapat memahamkan murid tentang kandungan mata pelajaran. Perkara ini dijelaskan oleh Hazim (M2S2 TS2:027). Sebahagian MURID bukan sahaja cenderung belajar secara amali, malah juga suka belajar dengan menunjukkan kemahiran di tempat duduk dan bukan pada situasi sebenar (M1S2 RVS2:006).

Walau bagaimanapun, MURID lebih cenderung untuk belajar secara amali kabir berbanding amali saghir (M2S2 TS2:027). Manakala Farzana (M2S1) tidak biasa dengan amali saghir ini kerana jarang didedahkan oleh gurunya kerana di dalam kelas gurunya mengajar teori sahaja tanpa ada contoh perbuatan kecil (M2S1 TS1:009). Bagi pembelajaran yang tidak melibatkan amalan, pengalaman pembelajaran berlaku di papan putih dan latihan bertulis. Pengalaman pembelajaran di papan putih adalah membaca nota ringkas di tulis guru dan penerangan bergambar seperti yang telah dijelaskan pada ciri visual alat bantu yang mana selain kad nota di papan putih, aktiviti membaca dan menulis juga berbantukan tulisan yang ditampal pada papan putih. Perkara ini berlaku kepada Hakim (M1S1) yang semangat ke depan kelas untuk aktiviti membaca atau menulis semasa pembelajaran tentang 
maksud solat (M1S1 RVS1:005). Hakim (M1S1) akan hilang mengantuk untuk terus fokus kepada pembelajaran apabila dapat melaksanakan pengalaman pembelajaran di papan putih. Begitu juga Farzana (M2S1) yang semangat untuk menjawab soalan ulangkaji sama ada soalan yang ditujukan kepadanya atau bertujuan membetulkan kesalahan rakannya (M2S1 RVS1:002).

Akhir sekali adalah ciri pengalaman melalui latihan bertulis yang melibatkan kecenderungan MURID belajar melalui aktiviti latihan bertulis. Aktiviti bertulis yang dimaksudkan ialah aktiviti sama ada dilakukan pada lembaran kerja atau buku tulis. Ciri ini amat sesuai kepada murid yang cekap dan cepat menulis serta memahami arahan aktiviti bertulis dengan baik (M1S1 OS1:017). Aktiviti pada lembaran kerja yang baik akan merangsang MURID berfikir. Hazim cuba mengingat semula perkara yang telah diajar oleh guru (M2S2 RVS2:052).

Selain latihan bertulis, guru juga membuat aktiviti menyalin nota yang merupakan aktiviti yang kurang menggunakan daya kognitif dan dianggap mudah oleh murid. Azam mempunyai kelebihan dalam aktiviti ini kerana dia dapat melaksanakannya dengan pantas. Sebaiknya guru mengambil kesempatan ini untuk memantapkan pengetahuan dan kemahiran Azam.

Kesimpulannya, melalui unsur persepsi, didapati ciri-ciri yang ditunjukkan oleh MURID ialah pembelajaran melalui visual, audio dan pengalaman. Oleh itu, pendekatan dan kaedah yang sesuai supaya MURID merasai sendiri pengalaman pembelajaran dengan melibatkan diri dalam aktivitiaktiviti yang dirancang seperti mewarna, amali, menulis di papan putih dan disusuli dengan latihan bertulis.

\section{Perbincangan}

\subsection{Gaya Pembelajaran Stimulus Persekitaran MURID}

Perbincangan pertama melibatkan Stimulus Persekitaran MURID di S1 dan S2 yang menyentuh tentang unsur bunyi, cahaya, suhu dan pola [32]. Unsur pola menunjukkan MURID belajar menghadap sumber selain belajar di tempat yang sunyi dan jauh daripada bunyi sama ada bunyi latar muzik atau bunyi bising pada unsur bunyi. Manakala bagi unsur cahaya, MURID cenderung dan boleh menerima maklumat dan kemahiran yang disampaikan melalui pembelajaran di dalam bilik darjah yang mempunyai sinar cahaya yang terang. Unsur ini wujud pada semua MURID S1-S2. MURID akan mengadu sekiranya mereka belajar di tempat yang tidak terang. MURID memerlukan cahaya yang terang semasa belajar sebagaimana diperincikan dalam Bab 4. Cahaya lampu kalimantang dan cahaya matahari merupakan alat yang diperlukan untuk mendapat cahaya yang cerah.

\subsection{Gaya Pembelajaran Stimulus Fisiologi}

Stimulus fizikal mengandungi empat unsur iaitu persepsi, makan, waktu dan gerakan. Kajian ini mendapati beberapa stimulus lain dalam Stimulus Fisiologi iaitu Stimulus Multi-sensori, Stimulus Lagu, Stimulus Qiraah dan Stimulus Tikrar. Unsur persepsi melibatkan ciri individu yang suka belajar dengan benda atau pengalaman maujud atau sebaliknya dengan perkara abstrak. Unsur makan melibatkan ciri individu yang suka atau sebaliknya tidak suka makan dan minum semasa belajar. Unsur waktu melibatkan ciri individu yang suka belajar pada waktu yang sesuai atau sebaliknya pada bila-bila masa sahaja. Unsur gerakan melibatkan ciri individu yang suka atau sebaliknya tidak suka bergerak semasa belajar.

Sebahagian besar jawapan terhadap persoalan ini datang daripada pemerhatian dan temu bual MURID sendiri. Persoalan gaya pembelajaran MURID dalam pengajaran dan pembelajaran (PdP) sebagaimana yang dijelaskan dalam dapatan kajian, memperlihatkan bahawa sebahagian besar MURID di S1 dan S2 adalah memiliki gaya pembelajaran stimulus fisiologi yang tidak terdapat dalam Model Dunn dan Dunn. Perkara ini merupakan dapatan baharu kajian ini. Begitu juga, tidak semua unsur pada stimulus fisiologi yang berdasarkan Model Dunn dan Dunn dimiliki oleh peserta. Sebahagian peserta memiliki unsur persepsi, masa dan suka pergerakan. Seorang peserta memiliki ketiga-tiga unsur yang dinyatakan, manakala tiga peserta lagi memiliki sekurang-kurangnya satu unsur. Terdapat seorang murid menunjukkan memiliki unsur mengambil masa senggang atau makan semasa pemerhatian dijalankan. Bagi unsur masa dimiliki oleh M1S2 dan unsur suka pergerakan dimiliki oleh M1S1, M1S2 dan M2S2 yang dapat dilihat semasa pemerhatian. Manakala M2S1 menyatakan dia tidak suka pergerakan (T4S1).

MURID suka kepada pembelajaran secara pandang dan dengar lagu yang dilakukan oleh guru melalui tayangan video nasyid. Kaedah ini melibatkan gaya pembelajaran Stimulus Multi-sensori. M3S1 dapat menjawab soalan yang diajukan guru secara lisan berkenaan kandungan video nasyid 
dalam perbincangan secara kelas. Menurut Mohamad \& Hashim [33], individu yang mempunyai persepsi auditori yang tinggi dapat belajar dengan berkesan sekiranya didedahkan kepada alatan audio yang khusus seperti radio, kaset dan vcd. Murid kategori ini akan mengingati maklumat yang didengar, mampu memberi tumpuan yang tinggi dan dapat menggambarkan suara yang didengari [34]. Diamping itu juga, kemahiran orality iaitu penghantaran lisan daripada guru kepada murid dan penyampaian ilmu secara tradisional perlu sesuai dengan kaedah ini dalam menyampaikan topik tertentu mata pelajaran Pendidikan Islam [35].

Manakala individu yang mempunyai persepsi visual lebih mudah menanggapi dan memahami maklumat dan kemahiran dengan bahan-bahan bantuan belajar seperti video, slaid, carta, televisyen, graf, gambar rajah dan ilustrasi [33] menjelaskan persepsi visual melibatkan tumpuan kepada aktiviti membaca secara paragraf dan muka surat. Menurut La Lopa [36], dalam menjelaskan teori gaya pembelajaran, menyatakan bahawa murid belajar dengan cara yang unik, biasanya dalam mod auditori, visual, dan kinestetik. Untuk meningkatkan prestasi murid, semua pendidik perlu lakukan adalah pertama mengenal pasti gaya pembelajaran murid dan kemudian sepadan cara mereka mengajar untuk setiap gaya. Oleh yang demikian, kajian ini telah mendapati penerimaan murid ini akan lebih mantap dan berkesan melalui gabungan persepsi audio dan visual.

\subsection{Aspek Teori dan Penghasilan Model daripada Pola Dapatan Kajian}

Ciri bagi setiap kategori kerangka kajian ini khususnya yang berkaitan dengan ciri gaya pembelajaran pada umumnya masih dalam peringkat teori yang belum dapat dibuktikan dengan kajian saintifik di lapangan melainkan kepada peserta kajian. Secara ringkas ciri gaya pembelajaran MURIDmerangkumi dua bahagian utama iaitu yang berasaskan Model Dunn \& Dunn dan yang bukan berasaskan Model Dunn \& Dunn sebagaimana digambarkan dalam rajah-rajah berikutnya. Selain itu rangsangan persekitaran juga telah mempengaruhi faktor wujudnya gaya pembelajaran tertentu pada MURID.

\section{Ringkasan}

Pengkaji telah membincangkan rumusan dapatan kajian dan perbincangan dapatan kajian dari perspektif teori. Seterusnya perbicaraannya juga menumpukan kepada aspek implikasi dapatan kajian terhadap penghasilan teori pada dapatan kajian sehingga menemukan model kajian. Dalam perbincangan implikasi ini juga pengkaji membincangkan cadangan yang bersesuaian dengan implikasi tersebut untuk pembaikan terhadap teori dan model dalam gaya pembelajaran, serta cadangan penggunaan model penemuan kajian untuk diaplikasikan dalam dunia pendidikan di Malaysia. Cadangan terhadap kajian mendatang disyorkan untuk dikaji bagi tujuan memperkukuh dan mempertingkatkan usaha pembaikan dalam pedagogi pendidikan.

\section{Rujukan}

[1] M. W. Ngware, M. Oketch, and M. Mutisya, "Does teaching style explain differences in learner achievement in low and high performing schools in Kenya?," International Journal of Educational Development, vol. 36, no. 1, pp. 3-12, 2014.

[2] M. R. Husin, N. M. Hassan, V. Y. Z. Sheng, A. S. M. Tormizi, N. S. A. Zulkapli, M. George, R. Rosli, N. I. R. A. M. Hishamuddin, N. S. Shaharudin, C. S. Adampai, "Perspektif Guru Terhadap Pembelajaran Pelajar Remaja", Journal of Humanities and Social Sciences, vol. 3, no. 1, pp. 40-49, Apr. 2021.

[3] J. M. Asio, "Sources of Information, Training Needs, Preparation and Response to Disaster of Selected Communities in Central Luzon, Philippines", International Journal of Humanities, Management and Social Science, vol. 4, no. 1, pp. 30-38, Jun. 2021.

[4] N. F. Mat Daud, N. A. S. Mat Yusoff, N. H. Mohd Azmi, S. Z. K. Mohd Asri, N. Z. Manisha Zaidi, and M. R. Husin, "Kerja Sambilan Mempengaruhi Ketidakhadiran Pelajar Tingkatan 3", Journal of Humanities and Social Sciences, vol. 3, no. 2, pp. 67-79, Aug.

[5] J. M. R. Asio, "The Relationship between Academic Procrastination and Academic Performance of Freshmen Students from a Teacher Education Institution", Journal of Humanities and Social Sciences, vol. 2, no. 3, pp. 105-115, Dec. 2020.

[6] M. Farhan, S. M. Hamil, N. N. Azmi, N. U. J. Roslid, N. N. Zainal, N. B. Kamaruddin, N. I. Hamizi, N. Z. Ismawi, M. R. Husin, "Masalah Pembelajaran untuk Pelajar Pendidikan Khas: 
Dana dan Prasarana", International Journal of Humanities, Management and Social Science, vol. 3, no. 1, pp. 1-10, Jun. 2020.

[7] S. N. Mail and L. F. Md Ibharim, "Pengaruh Sikap Terhadap Pelajar di UPSI Apabila Menggunakan Aplikasi Permainan Atas Talian", Journal of Humanities and Social Sciences, vol. 2 , no. 3 , pp. $82-87$, Dec. 2020.

[8] Z. Mohd Adnan and J. Hamid, "Kesan Model Polya Dalam Pembelajaran Algoritma Dalam Kalangan Pelajar: Satu Kajian Kes", Journal of Humanities and Social Sciences, vol. 2, no. 3, pp. 88-92, Dec. 2020.

[9] N. Laili, S. E. Purwanto, and F. Alyani, "Pengaruh Model Penemuan Terbimbing Berbantu LKPD terhadap Kemampuan Pemahaman Konsep Matematis Siswa SMPN 6 Depok", International Journal of Humanities, Management and Social Science, vol. 2, no. 1, pp. 14 - 37, Jun. 2019.

[10] N. M. Hassan, N. A. N. F. M. Noor, Y. Thasarathan, Q. N. Zainudin, N. S. A. Zainur, Nurul R. N. M. Rizuaden, N. A. M. Fauzi, N. Tumin, N. A. S. M. Jefri, "Perspektif Guru Terhadap Kemahiran Berfikir Aras Tinggi dalam Kalangan Pelajar", Journal of Humanities and Social Sciences, vol. 3, no. 2, pp. 50-56, Aug. 2021.

[11] A. Ismail, N. Z. Mohamed Zain, and H. Mat Zin, "A Simple Survey on Attitude of Computer Science Diploma Students towards STEM", International Journal of Humanities, Management and Social Science, vol. 2, no. 2, pp. 76 - 88, Dec. 2019.

[12] N. Abdul Rahim, N. A. Meor Fadzir, N. A. H. Zaimal, F. F. Arias Yahaya, Z. I. Zainol, and M. R. Husin, "Implikasi Gaya Pembelajaran Koperatif Subjek Sains Bagi Murid Tahap Dua di Sekolah Kebangsaan Bandar Baru Rawang", Journal of Humanities and Social Sciences, vol. 3, no. 2, pp. 57-66, Aug. 2021.

[13] L. Hernandez, "Strengths and Challenges of Distance Learning Modalities in the New Normal: Basis for Intervention Program", Journal of Humanities and Social Sciences, vol. 3, no. 2, pp. 80-87, Aug. 2021.

[14] M. Z. Mohd Nawi and M. A. Mohamed Noor, "Meningkatkan Kemahiran Mengingat Lima Hukum Asas Tajwid Dalam Tilawah Al-Quran", Journal of Humanities and Social Sciences, vol. 3, no. 1, pp. 23-32, Apr. 2021.

[15] N. Laili, "Hubungan Adversity Quotient dan Hasil Belajar Matematika Peserta Didik dalam Pembelajaran Jarak Jauh di SMP”, Journal of Humanities and Social Sciences, vol. 3, no. 1, pp. 33-39, Apr. 2021.

[16] Nur Syazlina Hanim, Jasmine Anak Jang, Nur Hana Afifa Jamal, Florance Duya Low, Salina Rentap, Nicorsons Anak Fabian, Gilbert Anak Gordion, Mohd Razimi Husin, "Pelajar Berkecerdasan Tinggi dalam Kalangan Pelajar Kelas Rancangan Khas", International Journal of Humanities, Management and Social Science, vol. 2, no. 1, pp. 1 - 13, Jun. 2019.

[17] C. Ifeakor, and A. I. Odo, "Analysis of the Marxist Theory on the Abolition of State: Its Implication to Nigeria Educational System", Journal of Humanities and Social Sciences, vol. 2, no. 2, pp. 62-68, Aug. 2020.

[18] N. M. Shahril Khuzairi, M. S. Sidhu, and Z. Che Cob, "Learning Analytics and Teaching Analytics: The Similarities and Differences", International Journal of Humanities, Management and Social Science, vol. 3, no. 2, pp. 52-58, Dec. 2020.

[19] T. Tripura, "Issues and Challenges Faced by the Indigenous Students of Tripura in Primarylevel to Higher Education: An overview", International Journal of Humanities, Management and Social Science, vol. 3, no. 2, pp. 59-67, Dec. 2020.

[20] R. Hashim and M. H. Mohamad Yatim, "Hubungan Antara Motivasi dan Penerimaan Dengan Pencapaian Akademik Pelajar Dalam Pembelajaran Menggunakan M-Pembelajaran di Kolej Vokasional", International Journal of Humanities, Management and Social Science, vol. 2, no. 2, pp. 89 - 94, Dec. 2019.

[21] M. Mansor, W. A. Wan Adnan, and N. Abdullah, "A Step-by Step Process in Designing Personalized Reading Content for Slow Learner Children", International Journal of Humanities, Management and Social Science, vol. 2, no. 2, pp. 95 - 102, Dec. 2019.

[22] A. D. Pyle, ADHD Focused Homework Intervention. San Francisco: University of the Pacific, 2009.

[23] D. A. Fine, Comparisons between the Learning Styles of Special and Regular-Education HighSchool Students and the Effects of Responssive Teaching on The Short-and Long-Term 
Achievement, Attitudes, and Behaviors of a Sub-Set of Special-Education Adolescents. New York: St. John's University, 2002.

[24] G. Hwang, H. Y. Sung, C. M. Hung, and I. Huang, "A Learning Style Perspective to Investigate the Necessity of Developing Adaptive Learning Systems," Educational Technology and Society, vol. 16, no. 2, pp. 188-197, 2013.

[25] S. M. Jais, A. R. Daud, M. A. S. M. Arip, and S. S. S. Salim, "Peranan kaunselor dalam pembentukan persekitaran dan pengalaman sekolah yang positif dalam kalangan murid berkeperluan khas," in Prosiding Persidangan Antarabangsa Pendidikan Khas 2012. Melaka: Hotel Mahkota, 2012.

[26] R. M. Gagne, L. J. Briggs and W. W. Wagner, Principles of Instructional Design (4 ${ }^{\text {th }}$. Ed.). New York: Harcourt Brace Jovanovich College Publisher, 1992.

[27] KPM Malaysia. Pekeliling Norma Baharu Guru Pendidikan Islam: Februari 2015. Kuala Lumpur: KPM, 2015.

[28] E. Howard, Handbook for Conducting School Improvement Project. India: Phi Delta Kappan, 1987.

[29] S. Sze, "Learning Style and the Special Needs Child," Journal of Instructional Psychology, vol. 36, no. 4, pp. 360-362, 2009.

[30] British Ministry of Education, Teaching Students with Autism: A resource Guide for Schools. Victoria: British Columbia, 2000.

[31] S. Cassidy, "Learning Styles: An Overview of Theories, Models, and Measures," Journal of Educational Psychology, vol. 24, no. 4, pp. 419-444, 2004.

[32] R. Dunn and S. A. Griggs, Multiculturalism and learning Style: Teaching and Counselling Adolescent. Westport, CT: Praeger, 1995.

[33] B. Mohamad and I. Hasyim. Gaya Pengajaran dan Pembelajaran. Kuala Lumpur: PTS Professional, 2010.

[34] R. Dunn and K. Dunn, Teaching Unsurtary Students through Their Individual Learning Styles: Practical Approaches For Grades 3-6.United States of America: Allyn and Bacon, 1992.

[35] G. Hardaker and A. A. Sabki, "An insight Into Islamic Pedagogy at the University of AlQarawiyyin," Multicultural Education and Technology Journal, vol. 6, no. 2, pp. 106-110, 2012.

[36] L. Lopa and J. M., "The Difference Between Bigfoot and Learning Styles: There May Be Better Evidence to Support the Existence of Bigfoot," Journal of Culinary Science \& Technology, vol. 11, no. 4, pp. 356-376, 2013. 